\title{
THE NIGHTMARE: GENETICALLY MODIFIED ORGANISMS AS ALIEN SPECIES
}

Meliha Merve HIZ * and Cüneyt AKI **

* Çanakkale Onsekiz Mart University, Faculty of Science and Arts, Department of Biology, Molecular Biology Subdivision, Çanakkale, Turkey, TR-17100, mervemeliha@comu.edu.tr

** Çanakkale Onsekiz Mart University, Faculty of Science and Arts, Department of Biology, Molecular Biology Subdivision, Çanakkale, Turkey, TR-17100, cuneytaki@comu.edu.tr

DOI: 10.1515/trser-2015-0008

KEYWORDS: genetically modified organisms (GMOs), biotechnology.

\section{ABSTRACT}

Biotechnological applications in medicine, industry and agriculture allow the economic production of important products, thus influencing national economy and revenue. Genetic modifications on microorganisms, plants and animals are major techniques to produce a desirable trait or product in biotechnological applications. However, GMOs also give rise to severe debate on aspects such as safety and environmental impact of transgenic products. In general these controversies arise as a result of misinformation. Ethical, legal and socially acceptable aspects of GMOs are strongly influenced by social, economic and political conditions, owing to the strong economic impact of high incomes for biotechnology companies.

RÉSUMÉ: Le cauchemar: les organismes génétiquement modifiés perçus comme des espèces envahissantes.

Les applications de la biotechnologie en médicine, industrie et agriculture permettent l'obtention de produits importants par des modalités économiquement intéressantes, influençant ainsi les économies et les budgets nationaux. Les modifications génétiques apportées aux microorganismes, aux plantes et aux animaux sont des techniques majeures utilisées afin d'obtenir un certain trait ou produit dans le cadre des applications biotechnologiques. Néanmoins les OGM sont aussi la cause des débats ardus sur la sécurité des produits transgéniques et leur impact sur l'environnement. Généralement ces controverses apparaissent à la suite d'une communication défectueuse. Les aspects éthiques, juridiques et sociaux par rapport à l'acceptation des OGM sont fortement influencés par le contexte social, économique et politique, à cause de l'impact économique important des revenus engendrés par les compagnies de biotechnologie.

REZUMAT: Coşmarul: organismele modificate genetic văzute ca specii invazive.

Aplicațiile biotehnologiei în medicină, industrie și agricultură permit obținerea de produse importante prin modalități interesante din punct de vedere economic, influențând pe această cale economiile și bugetele statelor. Modificările genetice aduse microorganismelor, plantelor și animalelor sunt tehnici majore utilizate pentru a obține o trăsătură dorită sau un produs dorit în cadrul aplicațiilor biotehnologice. Cu toate acestea, OMG-urile sunt și cauza unor dezbateri aprinse cu privire la siguranţa produselor transgenice sau cu privire la impactul lor asupra mediului. În general, aceste controverse apar datorită informării defectuoase. Aspectele etice, legale și sociale ale acceptării OMG-urilor sunt puternic influențate de contextul social, economic și politic, datorită impactului economic mare al veniturilor ridicate obținute de către companiile biotehnologice. 


\section{INTRODUCTION}

Genetically modified organisms (GMOs) are products of modern biotechnology that encapsulate any living organism containing a novel combination of genetic material other than the natural one. In fact, the logic of the process comes from a horizontal gene transfer that naturally occurs between different species and results in an alteration of the targeted genome. For example, Agrobacterium sp. is able to transfer small parts of its plasmid genome to plants; or lentiviruses can transfer their genes to animal cells. Many research groups aim to determine the function of the genes by mutation, recombination, and the addition or deletion of genetic material. Nowadays, the recombinant DNA technology is widely used to produce desirable phenotype such as resistance to pests or herbicides, as well as increased production capability or quality. Genetic modifications are also important to obtain desirable traits in animals such as featherless chickens, hypoallergenic pets and pharmaceutical camels. Also the data that is obtained from gene knockout, knockdown, targeting or sequencing research allows us to understand the molecular mechanism of the human diseases. Nowadays the genetic modifications are widely used for the production of commercially valuable proteins, humanized antibodies or vaccines in pharmaceutical industry. Actually, the major aim of the pharmaceutical companies is implementation of the personalized medical applications including gene therapy by the power of the valuable data that is gained from genetic research.

In white biotechnology, producers benefit from GM microorganisms and gain important opportunities to produce value added products, and also improve enhanced productivity and yield. White biotechnology techniques that remodel all of the processing procedure help to reduce the amount of input as well as output such as waste and $\mathrm{CO}_{2}$ emissions during the process by ways through which sustainable ecofriendly products with ruinous price can be achieved. The genetic manipulations can also be used to produce ecofriendly microorganisms that are able to clean up contaminated natural and semi natural aquatic, semiaquatic and terrestrial areas. On the other hand, risk assessment of GMO in aquatic and semiaquatic areas are more troublesome than terrestrial areas due to control in the network of interactions among species which is more difficult due to absence of safety borders. The powers of the genetic modifications are inconceivable, yet the fear over the genetic modifications that come from the unpredictable results force us to be cautious.

\section{The economic and politics aspect of GMO on Africa}

The debates related to GMO's are complex due to the power of GMO's and its related products on world economy. Nowadays the major problem comes from different views that originated by scientific and political arguments. South Africa, Burkina Faso and Egypt are three main African countries that have cultivated genetically modified crops in commercial basis (Adenle, 2011). The major problem of the African population is starvation due to drought, flooding, and poor harvests; as a result of this situation, importation of the quarter of African food causes economic crisis and collapsing of these areas because the majority of the public are engaged in agriculture (Cooke and Downie, 2010). Bioengineered plants and its products have strong economic impact due to high incomes for farmers as well as low prices and increased quality food for consumers (Anderson, 2010). Due to economic welfare gains from crop biotechnology, African and Asian countries support cultivation of biotech crops. On the other hand, until the third world countries develop scientific groundwork and reach high technological levels, their dependency to multinational companies and international research agencies cause a collapse of the third world countrys' economies. 
Kenya has claimed that GM crops are important to solve the world's starvation problem, thus GM varieties have such properties as early-maturing, drought, pest and disease resistance (Cartagena Protocol on Biosafety, 2010). Thus Kenya appealed to the African Union in January of 2013 to evaluate GM crops in aspects of economic, strategic and international profit (Hoefler, 2013). Kenya's Minister for Science and Technology declared that genetically modified organisms (GMOs) is crucial for economic and technological development, thus Kenya regulates its legal groundwork suitable to benefit from GM products. On the other hand, most of the African countries have obeyed the rules of Cartagena Protocol on Biosafety. For example, the Tanzanian government effort to develop its own National Biosafety Framework (NBF) to reduce the risks of modern biotechnology (Mugurusi and Mwinjaka, 2006), yet the knowledge and awareness of the public is not good enough. Tanzanian farmers do not raise awareness of potential risk of the GM crops. Unlike Tanzanian government farmers who attach importance to increase overall crop production rather than potential health or ecological related risk (Lewis et al., 2010).

Cassava (Manihot esculenta C.) is an important carbohydrate and micronutrient source in rural areas of Africa, Asia, and Latin America, yet in case of nutritional deficiencies or inadequate process of the plant results neurotoxicity due to its high content of cyanogenic glycoside (Rivadeneyra-Domínguez et al., 2013). The genetically modified cassava is important for food and feed safety as well as enhanced starch production (Ihemere et al., 2006; Jansen van Rijssen et al., 2013), thus GM cassava is an important food crop that is used by more than 500 million people. An another important source of caloric intake in the tropical African people diet is maize (Miracle, 1966). Genetically modified maize that is resistant to insects and drought is cultivated in Kenya, South Africa, Tanzania, Uganda, and Zimbabwe; and up to $80 \%$ of cultivated white maize is genetically modified in South Africa.

\section{Debates related to biosafety of the GM products}

Genetically modified product has already been on the market without labeling. The presence of Starlink corn and Roundup Ready soybean was found on the Egyptian food market (Elsanhoty et al., 2002). Elsanhoty et al. (2002) have often detected genetically modified rice, maize, and soy by qualitative and quantitative DNA-based methods in Saudi food products (Elsanhoty et al., 2013). Rabiei et al. (2013) demonstrated the presence of GM maize in Iranian specific food products by qualitative PCR. In another study, fresh and processed foods were screened to check genetic modifications by SYBR green-based, real time polymerase chain reaction (RT-PCR) method in Kuwait and positive results were obtained from the samples (Al-Salameen et al., 2012). Genetically modified organisms were also found without labeling on food and animal feed in China (Zhou et al., 2005).

Sieradzki and colleagues have shown how GM DNA is digested as well as their conventional counterparts; but no samples were obtained from animal tissue the GM DNA transfer from feed to animal tissues and bacterial gut flora (Sieradzki et al., 2013). Another study that was performed on animals showed that diets containing GM maize, potato, rice or soybean are nutritionally equivalent to their non-GM counterparts and are also safe for human and animals (Snell et al., 2012). Snell et al. (2012) have evaluated long-term as well as multigenerational animal feeding studies via systematic 
review of many data that included: biochemical analyses, histological examination of specific organs, haematology and the detection of transgenic DNA from different studies; yet any significant differences between GM plants and non-GM counterparts could not be found (Snell et al., 2012). Besides these studies, Séralini et al. (2012) performed a study that aimed to show life-long consumption of an agricultural genetically modified organism (Séralini et al., 2012), yet this publication caused speculation and many comments were sent to authors; consequently, journals withdrew the paper. The main reason of this speculation was Séralini and colleagues preferred a rat strain that were prone to cancer and also mycotoxin content in the feed could trigger cancer initiation as well as GM feed (Pilu, 2013). None of these specific studies showed till the present long term cumulative negative effects of genetically modified organisms efficiently, thus there are numerous concerns related to GMO's due to uknown/unpredictable effects on human health and environment.

One of the important questions related to GM plant derived food and feed is allergenic reactions based on the fact that transgene can be identical to an allergen in a different food source (Panda et al., 2013). The second inquietude is the potential risk of conversion of non-toxic amino acid sequences to toxic compounds after modification of proteins (Hammond et al., 2013). Another apprehension is denaturation of the protein during the processing conditions to functionally active proteins that are harmful to human health (Hammond et al., 2013). Thus both labeling and traceability is crucial to obtain risk assessment of GM products. The European Union has strict regulations and policyes to protect human life, health and welfare aside assessment of environmental risks due to the questions regarding GMOs' safety (Davison, 2010). European Commission has authorized food and feed ingredients containing, consisting of, or produced from different GM products such as cotton, maize, potato, soy-bean or sugar beet; yet authorization for usage varies among GM products due to genetic characteristics (European Commission Report, 2012). In the European Union, common procedures for risk assessment and authorization are efficient to protect human, animal, and plant health as well as prevent the spread of the GMOs' slaughter of biodiversity.

The current status of Turkey: in 1993, "Biodiversity Convention" is a global agreement addressing the regulation related to biodiversity and was signed by a total number of 156 countries including Turkey, then the complementary regulation "Cartagena Protocol on Biosafety" has been approved in 2004. The legal regulation related to GMOs' production, consumption and inspection was first legally regulated and for the first time genetically modified product definition was enacted in Turkey in 2004. In 2009 another specific regulation that aims to regulate and control importations, exportation and also processing of GMOs' as food and feed additives has entered into force in Turkey. The procedures and principles that regulate the establishment and implementation of biosafety systems includes control, regulation and monitoring of these systems to prevent risks arising from GMOs which were determined within the scope of "Bio safety Law" in 2010.

\section{The nightmare of genetic modifications}

The long term effects of the GMOs on human beings or the environment is not clear, thus public reaction is worrisome due to information pollution. The main question is whether GMOs are an environmental threat or ecological risk to the universe. The debate comes from the fact that genetically modified organisms are seen as alien species that are able to spread out and supplant native species. The hypothetical risk is if a 
transgene will be invasive and flow throughout species and cause new ecologically harmfull phenotypes or alter the current metabolic pathways and thus produce more toxic compounds.

The fear of the transgene dispersal can be a result of transportation by pollen migration or mixing the GM and non-GM seeds (Ricroch et al., 2009). Pollen mediated gene flow can occur between transgenic plant and wild races and related species (Tang et al., 2005; Hüsken and Dietz-Pfeilstetter, 2007). The transgene transportation by pollen migration can cause an increase in the recessive alleles frequencies and both recessive alleles and transgenic alleles can be distributed quite quickly, especially in selfing plants. The cross pollination is also another important challenge due to the capability of introducing the altered gene in the normal plant via pollination with GM plants. Galeano and colleagues performed a study in Uruguay and the results of the study showed that the transgenic pollen were spread out of the control area and $0.13 \%$ of the transgene were determined in the offspring of the non-GM crops (Galeano et al., 2010). Transportation of the transgenic plants are also a potential risk to biodiversity. Waminal and colleagues have shown that genetic alteration on wild type race in different private farms and public areas near a transportation route of genetically engineered maize (Waminal et al., 2013). The other drawback is that weeds can gain resistance genes from GMO's via cross-pollination of the weeds by resistant plants. The gene flow between the crop and certain weeds can cause weeds that have resistance to different herbicides to obtain an advantage. Terminator gene technology that allows inhibiting cross pollination by producing sterile seeds from the genetically modified plant could be a solution to prevent herbicide-resistant biotypes of weeds. On the other hand, terminator gene technology causes extra economic burdens to farmers due to the requirement of re-purchasing the non-sterile seed each year. This point also explains why genetically modified crops could not be the solution of economic crisis in third world countries.

Aside from terrestrial ecosystems, genetic modifications can be seen as a threatening problem for the natural and seminatural aquatic and semiaquatic ecosystems diversity. In fact, in aquatic and semiaquatic systems, utilization of the genetic modifications in plants are more troublesome because the prevention of the gene flow can not be gained via safety borders. Nowadays, genetically modified algae and its biomass are important for biofuel production, yet during the cultivation process, gene flow or mono cultivation are the major problems for aquatic ecosystems. On the other hand, monitoring the area is crucial to gain biosafety of the other aquatic organisms such as fish or crustaceans. In aquatic ecosystems, controlled passing of the organisms or the intervention via direct regulation of the control is impossible by biosafety borders.

In the views of aquatic and semiaquatic organisms, escape of transgenics organisms are a threatening problem for aquatic communities. Introduction of transgenic fish that are capable to grow up more easily than its counterpart cause substantial shifts in aquatic ecosystems and culminate as a transgenic dominant species. Furthermore, that situation causes a lose of genetic diversity and as a result causes elimination of the recessive traits and also increase the transgenic allele frequencies. Due to that reason, considerable efforts must be shown for controlling and monitoring the GM organisms for effective ecosystem management. 


\section{Biotechnology in ecological aspects}

Biotechnological application on the industrial process allows the design of desirable phenotypes in order to produce important industrial products by creating value-added products with advanced technology. Metabolic engineering is a process that allows changing metabolic pathways to produce industrial and pharmaceutically important molecules such as valuable proteins, polypeptides, as well as primary and secondary metabolites. For example, rational design of the metabolic pathway of $S$. cerevisae allows resistance to oxidative stress and this helps to reduce the requirements of the microbial process and also increases the yield process and allows easily optimizing fermentation processes which increases the yield give advantage to reduce the amounts of toxic waste.

Biotechnical principles allow toxicity reduction of the conventional process via replacement of biotechnological methods or biodegradation of industrial pollutants. For example, creating the product via manipulation of the enzymatic process instead of chemical usage allows the reduction of toxic chemical requirements, thus finding ecological friendly solutions during the production process. In fact, enzymes have been used for a long time in industrial application, but the genetic manipulations on microorganisms yield super enzymes that have high substrate, specificity and catalytic properties such as maximum efficiency at a desired temperature with lower feedback inhibition properties. For example, genetically modified lipases and esterases are mainly used in biofuel production, textile processing, waste treatment, and also preferred as detergent additives in industry.

By ecological aspects, the organic wastes or microbial bulk can be used to produce biofuels (hydrogen or ethanol) and those new renewable energy alternatives are different from natural fuels or nuclear fuel with its ecological friendly properties. If the biofuel contaminations occur due to spills, these biomolecules can be easily degragate in the environment. Although biofuels have the same emission with fossil fuels, biofuels are still the best alternative due to low sulfur content, therefore biofuels are a good alternative to protect the earth against acid rain. In another perspective, the countries that have enough land area can profit from biofuel protection in commercial basis and gain its economic independence from fossil fuel producing countries.

Genetically modified organisms can be used for bioremediation of contaminated water and landscape via conversion of organic compounds into smaller pieces (biotransformation) or complete convertion of the cell mass by mineralization of organic molecules until $\mathrm{CO}_{2}$, water and inorganic elements which turn into inorganic compounds (mineralization). Genetic modification of the microorganisms also allows coagulating sedimentation of the colloidal solids in wastewater and resolves organic matter for stabilization. Bioremediation occurs via genetically modified organisms or products of GMOs by reducing the nitrogen and phosphorus content in domestic and agricultural wastewater. For example, pesticide contaminated water can be cleaned by organophosphate degrading enzymes that immobilized on nonwoven polyester textiles (Gao et al., 2014). In another example, purification of oil pollution at sea can be achieved by genetic modification of the Proteobacteria, Pseudomonas and Cycloclasticus, and this is important to break down spilled hydrocarbon quickly during accidents such as Exxon Valdez. After the Exxon Waldez accident, scientists performed a study to produce transgenic Pseudomonas that are capable to degradate petroleum as a nutrient source to survive and clean-up aquatic areas quickly and safely in extreme cold conditions. Removing hazardous chemicals from industrial wastewater is an ecologically important application of biotechnology. For example, industry, textile effluent contaminated environments can easily be cleaned up from malachite green dye by Ochrobactrum sp. (Vijayalakshmidevi and Muthukumar, 2013). Polluting effects of diesel 
fuel, the process and mechanism of its biodegradation, the role of different microbes having degradation potential and their application strategies, were under the scientists attention (Bhawsar and Cameotra, 2011).

On the other hand, bioterrorism can be a major fear for aquatic, semiaquatic and terrestrial ecosystems because genetically modified organisms can easily adapt to specific environments and can be the dominant species in an extremely short period of time.

If we think about the transfer of insects that gain resistance to different categories of insecticide and damage ecological systems and their specific balance or cultivation of herbicide and pesticide resistant weed species by enemies. Simply, bioterrorist application contaminates water by infectious genetically modified microorganism that are resistant to antibiotics.

Kenya has claimed that GM crops are important to solve the world's starvation problem, thus GM varieties have such properties as early-maturing, drought, pest and disease resistance which will be promote to utilization (Cartagena Protocol on Biosafety, 2010). Thus Kenya appealed to the African Union in January of 2013 to evaluate GM crops in aspects of economic, strategic and also so called international profit (Hoefler, 2013). Kenya's Minister for Science and Technology declared that genetically modified organisms (GMOs) are crucial for economic and technological development, thus Kenya's regulation of its legal groundwork is suitable to benefit from GM products.

On the other hand, most of the African countries have wiselly obeyed the specific rules of Cartagena Protocol on Biosafety. For example, the Tanzanian government's effort to develop its own National Biosafety Framework (NBF) to reduce the risks of modern biotechnology (Mugurusi and Mwinjaka, 2006), yet the knowledge and awareness of the public is not good enough. Tanzanian farmers are not aware of the potential risk of the GM crops. Unlike the Tanzanian government, farmers attach importance to increase overall crop production rather than potential health or ecological related risk (Lewis et al., 2010).

\section{CONCLUSIONS}

There is an ongoing international debate related to genetic engineering of organisms in order to produce desirable phenotype.

The general public opinion and power of civil society activist groups draws attention to genetically modified organisms and try to force the governments to legally see how to make arrangements that also seal countries' fate on economic and politics areas.

In green biotechnology, the principal advantage of genetic modifications is a significant improvement of food taste and texture, nutritional value and crop yield as well as the reduction in crop susceptibility to different pathogens and also environmental stresses.

The general disadvantage seems to be connected with health and environmental risk. The possibilities of allergic and toxic reactions, loss of biodiversity, genetic pollution, ecotoxicity are main concerns over GMOs. 
The most important economic disadvantage of the green biotechnology is to transform biotechnological seed companies into a global monopoly and cause poorer farmers.

In red biotechnology the genetic modifications allow scientists to grasp a better understanding of molecular mechanisms of diseases. New generation of biopharmaceuticals will improve drug safety. Pharmacogenomics allows personalized medicine rather than "one drug fits all” and that improves an individual's response to drugs by optimizing drug dosage, maximizing therapeutic effect and minimizing side effects. The main controversy over red biotechnology is discrimination of the indivuals due to genetic information of the databases. The main disadvantage comes from the fact that leakage of medical or genetic information causes non-ethical approaches and behaviors by private insurers or employers.

Innovations in industrial biotechnology allow to create new products or to improve the existing production processes. This knowledge based technology provides sustainable development for countries producing value-added co and by-products of bioprocesses. Metabolic engineering, fermentation technology and production of bio-fuels are the main research focus on white technology. The main advantage of white biotechnology is protection of environment and ensures healthy eco-systems. If handled properly, all parts of biotechnology benefits humankind, yet the careless and non-ethical usage of the technology may cause disasters like the nuclear bomb. 


\section{REFERENCES}

1. Adenle A. A., 2011 - Response to issues on GM agriculture in Africa: Are transgenic crops safe? BMC Research Notes, 4, 388.

2. Al-Salameen F., Kumar V., Al-Aqeel H., Al-Hashash H. and Hejji A. B., 2012 - Detection of genetically modified DNA in fresh and processed foods sold in Kuwait, GM Crops Food, 3, 4, 283-288.

3. Anderson K., 2010 - Economic impacts of policies affecting crop biotechnology and trade, New Biotechnology, 27, 558-564.

4. Bhawsar S. and Cameotra S. S., 2011 - Biodegradation of diesel fuel, Transylvanian Review of Systematical and Ecological Research, The Wetlands Diversity, Curtean-Bănăduc et al., (eds), 12, 169-180.

5. Cooke J. G. and Downie R., 2010 - African Perspectives on Genetically Modified Crops Genetically Modified Crops Assessing the Debate in Zambia, Kenya and South Africa, A Report of the CSIS Global Food Security Project, Center for Strategic and International Studies, Washington, USA.

6. Davison J., 2010 - GM plants: Science, politics and EC regulations, Plant Science, 178, 2, 9498.

7. Elsanhoty R. M., Al-Turki A. I. and Ramadan M. F., 2013 - Prevalence of genetically modified rice, maize, and soy in Saudi food products, Applied Biochemistry and Biotechnology, 171, 4, 883-899.

8. $\quad$ Elsanhoty R., Broll H., Grohmann L., Linke B., Spiegelberg A., Bögl K. W. and Zagon J. 2002 - Genetically modified maize and soybean on the Egyptian food market, Nahrung, 46, 5, 360363.

9. European Commission, 2012 - Register of genetically modified food and feed European Commission, Health and Consumers, EU register of authorised GMOs Available at: http://ec.europa.eu/food/dyna/gm_register/index_en.cfm (10.12.2013).

10. Galeano P., Debat C. M., Ruibal F., Fraguas L. F. and Galván G. A., 2010 - Cross-fertilization between genetically modified and non-genetically modified maize crops in Uruguay, Environmental Biosafety Research, 9, 3, 147-154.

11. Gao Y., Truong Y. B., Cacioli P., Butler P. and Kyratzis I. L., 2014 - Bioremediation of pesticide contaminated water using an organophosphate degrading enzyme immobilized on nonwoven polyester textiles, Enzyme and Microbial Technology, 10, 54, 38-44.

12. Hammond B., Kough J., Herouet-Guicheney C. and Jez J. M., 2013 - Toxicological evaluation of proteins introduced into food crops, Critical Reviews in Toxicology, 43, 2, 25-42.

13. Hüsken A. and Dietz-Pfeilstetter A., 2007 - Pollen-mediated intraspecific gene flow from herbicide resistant oilseed rape (Brassica napus L.), Transgenic Research, 16, 5, 557-69.

14. Ihemere U., Arias-Garzon D., Lawrence S. and Sayre R. 2006 - Genetic modification of cassava for enhanced starch production, Plant Biotechnology Journal, 4, 453-465.

15. Jansen van Rijssen F. W., Morris E. J. and Eloff J. N., 2013 - Food Safety: Importance of Composition for Assessing Genetically Modified Cassava (Manihot esculenta Crantz), Journal of Agricultural and Food Chemistry, 61, 8333-8339.

16. Lewis C. P., Newell J. N., Herron C. M. and Nawabu H., 2010 - Tanzanian farmers' knowledge and attitudes to GM biotechnology and the potential use of GM crops to provide improved levels of food security, A Qualitative Study, BMC Public Health, 12, 407.

17. Mugurusi K. and Mwinjaka S., 2006 - National Biosafety Framework for Tanzania: Regulatory regime on genetically modified organisms, in Rege J. E. O., Nyamu A. M. and Sendalo D. (eds), The role of biotechnology in animal agriculture to address poverty in Africa: Opportunities and challenges, Proceedings of the 4th All Africa Conference on Animal Agriculture and the 31st annual meeting of Tanzania Society for Animal Production, Arusha, Tanzania, 20-24 September 2005, Dar es Salaam, Tanzania: TSAP and Nairobi, Kenya: ILRI. 
18. Panda R., Ariyarathna H., Amnuaycheewa P., Tetteh A., Pramod S. N., Taylor S. L. BallmerWeber B. K. and Goodman R. E., 2013 - Challenges in testing genetically modified crops for potential increases in endogenous allergen expression for safety, Allergy, 68, 2, 142-151.

19. Pilu R., 2013 - Long term toxicity of a Roundup herbicide and a Roundup-tolerant genetically modified maize, Food and Chemical Toxicology, 53, 454.

20. Rabiei M., Mehdizadeh M., Rastegar H., Vahidi H. and Alebouyeh M., 2013 - Detection of genetically modified maize in processed foods sold commercially in Iran by qualitative PCR, Iranian Journal of Pharmaceutical Research, 12, 1, 25-30.

21. Ricroch A., Bergé J. B. and Messéan A., 2009 - Literature review of the dispersal of transgenes from genetically modified maize, Comptes Rendus Biologies, 332, 10, 861-75.

22. Rivadeneyra-Domínguez E., Vázquez-Luna A., Rodríguez-Landa J. F. and Díaz-Sobac R., 2013 - Neurotoxic effect of linamarin in rats associated with cassava (Manihot esculenta Crantz) consumption, Food and Chemical Toxicology, 59, 230-235.

23. Séralini G. E., Clair E., Mesnage R., Gress S., Defarge N., Malatesta M., Hennequin D. and de Vendômois J. S., 2012 - Long term toxicity of a Roundup herbicide and a Roundup-tolerant genetically modified maize, Food and Chemical Toxicology, 50, 11, 4221-4231.

24. Sieradzki Z., Mazur M., Kwiatek K., Swiatkiewicz S., Swiatkiewicz M., Koreleski J., Hanczakowska E., Arczewska-Włosek A. and Goldsztejn M., 2013 - Assessing the possibility of genetically modified DNA transfer from GM feed to broiler, laying hen, pig and calf tissues, Polish Journal of Veterinary Sciences, 16, 3, 435-441.

25. Snell C., Bernheim A., Bergé J. B., Kuntz M., Pascal G., Paris A. and Ricroch A. E. 2012 Assessment of the health impact of GM plant diets in long-term and multigenerational animal feeding trials: a literature review, Food and Chemical Toxicology, 50, 3-4, 1134-1148.

26. Tang G., Song W. and Zhou W., 2005 - Gene flow and its ecological risks of transgenic oilseed rape (Brassica napus), Ying Yong Sheng Tai Xue Bao, 16, 12, 2465-8.

27. Unknown, 2010 - Cartagena Protocol on Biosafety: Fifth meeting of the Conference of the Parties UN conference adopts international liability rules for ecological damage resulting from genetically modified organisms, available at: http://dev.gmo-safety.eu/news/1233.conferenceadopts-international-liability-rules-ecological-damage-resulting-genetically-modified-organism s.html (10.12.2013).

28. Vijayalakshmidevi S. R. and Muthukumar K., 2013 - Biodegradation of malachite green by Ochrobactrum sp., World Journal of Microbiology and Biotechnology. (in printing)

29. Waminal N. E., Ryu K. H., Choi S. H. and Kim H. H., 2013 - Randomly Detected Genetically Modified (GM) Maize (Zea mays L.) near a Transport Route Revealed a Fragile 45S rDNA Phenotype PLoS One. 9, e74060.

30. Zhou J. C., Yang M. J., Yang X. F. and Huang J. M., 2005 - Detection of genetically modified organisms in food and animal feed by polymerase chain reaction, Wei Sheng Yan Jiu, 34, 6, 732-734 